\title{
KAJIAN KOMPLEKSITAS PROYEK KONSTRUKSI : TINJAUAN KEGIATAN PENGADAAN PEKERJAAN KONSTRUKSI DI INDONESIA
}

\author{
Cut Zukhrina Oktaviani ${ }^{1}$ \\ ${ }^{1}$ Universitas Syiah Kuala \\ Email: cut.zukhrina@unsyiah.ac.id
}

\begin{abstract}
ABSTRAK
Makalah ini bertujuan untuk mengkaji kompleksitas proyek konstruksi dalam pengadaan kompleks konstruksi. Kompleksitas konstruksi dipengaruhi oleh banyak faktor internal dan eksternal. Kompleksitas mencakup seluruh siklus proyek konstruksi. Pada tahap pengadaan pekerjaan konstruksi, kompleksitas organisasi dan proses menjadi perhatian utama terutama dalam pengadaan pemerintah. Kompleksitas membutuhkan pengaturan dan pengendalian yang sedemikian rupa sehingga tidak terjadi hambatan pada setiap tahapan siklus konstruksi proyek.
\end{abstract}

Kata kunci: Kompleksitas, Konstruksi, Pengadaan

\begin{abstract}
This paper aims to reviewed construction projects complexity in construction complex procurement. Construction complexity is influenced with many internal and external factors. Complexity covers entire construction project cycles. At construction work procurement stage, organization and processes complexity is a major concern, especially in government procurement. Complexity requires regulation and control are such that it does not happen obstacles at every project construction cycle stage.
\end{abstract}

Keywords: Complexity, Construction, Procurement 


\section{PENDAHULUAN}

Pelaksanaan proses produksi pada proyek konstruksi lebih bersifat spesifik yang dibatasi oleh kerangka waktu, mutu dan biaya berbeda dengan manufaktur yang dilakukan secara linear dengan struktur organisasi terorganisir, terencana dan terkelola dari atas ke bawah. Pelaksanaan proses produksi pada proyek konstruksi seharusnya dipandang sebagai suatu proses yang tidak hanya berjalan secara linear, akan tetapi pada tahapan tertentu harus dilakukan secara terintegrasi. Berbagai permasalahan terkait dengan ketersediaan sumber daya, keterlambatan waktu penyelesaian menjadikan proyek konstruksi seharusnya juga dilihat sebagai proses yang kompleks dan dinamis (Bertelsen, 2003). Sejalan dengan perkembangan kebutuhan dan pemahaman proyek konstruksi sebagai sistem dinamis yang kompleks menjadikan kompleksitas proyek konstruksi semakin lama semakin meningkat (Bertelsen, 2006:1).

Xia dan Chan (2011:8) menyatakan bahwa kompleksitas proyek konstruksi secara signifikan memberikan dampak terhadap berbagai aspek hasil pelaksanaan proyek, seperti waktu, biaya dan kualitas (Gidado dan Millar, 1992; Raymond, 1995; Walker dan Sidwell, 1996; Chan dan Kumarawwamy, 1997; Chan, 1998; Dissanayaka dan Kumaraswamy, 1999; Tatikonda dan Rosenthal, 2000; Nassar dan Hegab, 2006). Sebagai pihak yang secara langsung terlibat dalam proses produksi, kontraktor pelaksana haruslah memiliki pemahaman yang cukup terhadap kompleksitas konstruksi dan bagaimana mengelolanya sehingga akan menghasilkan konstruksi sesuai quality assurance yang ditetapkan.

Kontraktor pelaksana yang memiliki kompetensi akan dihasilkan oleh proses pengadaan yang berjalan dengan baik. Pemahaman pelaksana pengadaan terhadap kompleksitas pekerjaan konstruksi yang akan dilelangkan menjadi sangat penting untuk memastikan kompetensi dari penyedia jasa terhadap pekerjaan konstruksi yang dilelangkan. Terlebih lagi beberapa penelitian memperlihatkan bahwa ada hubungan tidak langsung antara hasil pelaksanaan pengadaan dengan kualitas hasil pelaksanaan pekerjaan (Wiyana, 2012; Yunus, 2006; Larasati, 2011; Kashiwagi \& Byfield, 2002, Winch, 2000; Crowley \& Hancher, 1995; Hatush \& Skitmore, 1997; Fong \& Choi, 2000; Kumaraswamy, 1996; Latham, 1994; Lingard et.al., 1998; Merna \& Smith, 1990; Russell,1996; Wong et.al., 2000, Mangitung, 2005; Nissen, 2007).

Pemahaman kompleksitas konstruksi secara tidak langsung akan memberikan kontribusi yang cukup signifikan terhadap pengelolaan pengadaan. Dengan adanya pemahaman ini diharapkan proses perencanaan pengadaan dan pemilihan dapat berjalan dengan baik sehingga akan menghasilkan kontraktor yang berkompeten dan mampu untuk melaksanakan tugas dan tanggung jawabnya. Dengan demikian, pemahaman terhadap kompleksitas proyek konstruksi sebaiknya diselaraskan dengan upaya pengelolaan, sehingga quality assurance yang diharapkan dapat tercapai. Sejalan dengan uraian tersebut diatas, makalah ini dimaksudkan untuk mengkaji kompleksitas konstruksi terutama terkait dengan pelaksanaan pengadaan pekerjaan konstruksi pemerintah berdasarkan literatur terkait dengan harapan membuka wacana pemahaman yang lebih baik.

\section{METODE}

Makalah ini merupakan hasil kajian deskripstif dari berbagai literatur, peraturan perundangan terkait dan berbagai informasi yang relevan dengan komplesitas proyek konstruksi dalam pelaksanaan pengadaan pekerjaan komplek pemerintah. Dengan adanya pemaparan hasil kajian teoritis pada makalah ini diharapkan akan membuka wacana pemahaman bagi semua pihak. 


\section{HASIL DAN PEMBAHASAN}

\section{Definisi kompleksitas}

"Kompleksitas" berasal dari kata "kompleks" yang berdasarkan KBBI memiliki arti himpunan; kesatuan; kelompok; mengandung beberapa unsur yg pelik, rumit, dan sulit. Oxford Dictionary mendefinisikan "consisting of parts, composite, complicated", sementara The Collins English Dictionary (2006) mendefinisikan "the state or quality of being intricate or complex", dimana complex didefinisikan "made up of many interconnecting parts".

Edmonds (1999) mendefinisikan kompleksitas sebagai bagian model yang relatif cukup sulit untuk merumuskan dalam bahasa tertentu dari suatu perilaku, bahkan jika informasi yang ada cukup lengkap dalam menggambarkan komponen terkecil dan hubungan yang ada. Berbicara tentang kompleksitas secara tidak langsung maka akan membahas tentang kompleksitas sistem dan proses (Schalcher, 2007:1). Berdasarkan beberapa pengertian diatas dapat disimpulkan bahwa kompleksitas merupakan kesatuan dari bagian-bagian yang komposit, rumit dan terkoneksi antar bagiannya.

\section{Kompleksitas proyek konstruksi}

Kompleksitas konstruksi dapat dipahami sebagai variasi dari beberapa bagian pekerjaan yang saling berkaitan dan dapat dilaksanakan dalam konteks perbedaan serta saling ketergantungan (Baccarini, 1996). Pemahaman ini haruslah dilihat dari berbagai dimensi proyek yang relevan dengan konsep manajemen proyek seperti organisasi, teknologi, lingkungan, informasi, pengambilan keputusan dan sistem.

Dengan demikian manakala berbicara tentang kompleksitas proyek adalah merupakan suatu hal penting untuk menyatakan dengan jelas jenis kompleksitas yang ditangani. Kompleksitas proyek konstruksi dapat didefinisikan dari (1) perspektif manajerial, yaitu melakukan perencanaan untuk menyatukan berbagai bagian pekerjaan sehingga membentuk suatu alur kerja dan (2) perspektif operasi dan teknologi, dimana terdapat keterlibatan seluk-beluk teknis atau tingkat kesulitan dalam melaksanakan bagian pekerjaan (Gidado, 1996; Baccarini, 1996).

Pemahaman kompleksitas proyek
menjadi penting terutama dalam menentukan metode perencanaan, metode pengadaan, koordinasi dan persyaratan pengawasan; menjadi faktor penghambat dalam proses identifikasi yang jelas tujuan dan sasaran proyek-proyek besar; merupakan salah satu kriteria penting dalam pemilihan proyek sesuai dengan bentuk organisasi; mempengaruhi dalam pemilihan sumber daya pengelola proyek; menjadi kriteria dalam pemilihan jenis pengadaan yang akan digunakan; mempengaruhi quality assurance dari proyek, yaitu mutu, biaya dan waktu (Chan 1998, Akintoye, 2000, Shiua dkk, 2006, Xia dan Chan, 2011).

Kompleksitas konstruksi juga dapat dilihat dari tiga perspektif (Bertelsen, 2003), yaitu proyek merupakan proses perakitan yang seringkali lebih rumit, paralel dan dinamis; konstruksi sangat terfragmentasi, dimana para pelaku bekerjasama dengan pola yang terus berubah dan proses pengadaannya dilakukan berdasarkan 
penawaran terendah; dan lokasi proyek selain merupakan tempat bekerja juga tempat interaksi sosial, dimana sistem kemanusiaan yang terbentuk bersifat sementara dan akibatnya tingkat pergantian sumber daya manusia tinggi sementara loyalitas rendah. Perbedaan karakteristik proyek antara satu proyek dengan lainnya menyebabkan banyaknya jenis dan variasi dari faktor yang mempengaruhi kompleksitas proyek konstruksi, dengan kata lain, faktor-faktor tersebut tidaklah bisa digeneralisasi secara spesifik. Terlebih lagi jika dilihat dari konteks publik dan swasta, tentunya akan banyak perbedaan karakteristik dan faktor kompleksitas yang akan mempengaruhinya.

\section{Kompleksitas stakeholder}

Sebagaimana pekerjaan/proyek lainnya, pada proyek konstruksi juga terdapat stakeholder baik internal maupun eksternal, yang memberikan pengaruh secara langsung maupun tidak langsung. Jumlah stakeholder proyek konstruksi relatif besar, termasuk di dalamnya pemilik proyek, pengguna fasilitas, manajer proyek, konsultan perencana, pemegang saham, kontraktor, subkontraktor, supplier, perusahaan asuransi, bank, media, lingkungan dan lain sebagainya sebagaimana terlihat pada Gambar 1. Dengan karakteristik wilayah Indonesia yang berupa kepulauan dan sistem pemerintahan desentralisasi kompleksitas stakeholder pekerjaan konstruksi akan semakin kompleks. Masing-masing pihak mempunyai peran dan pengaruh yang berbeda pada setiap tahapan proyek baik secara langsung maupun tidak langsung.

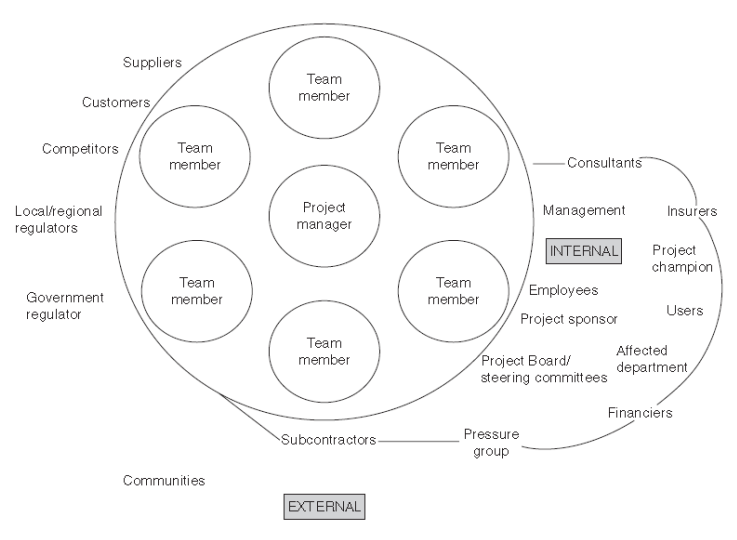

Gambar 1 Stakeholder proyek konstruksi (Chinyio dan Olomolaiye, 2010)

\section{Kompleksitas organisasi}

Kompleksitas organisasi secara umum dapat dilihat dari sisi differensiasi dan interdepedency. Differensiasi melihat hubungan yang terjadi dalam organisasi proyek yang meliputi komunikasi, pelaporan, wewenang pengambilan keputusan, pembagian tugas dan tanggung jawab. Dalam pelaksanaan proyek keterlibatan banyak pihak seperti pemilik, kontraktor, sub-kontraktor, supplier untuk suatu periode tertentu menyebabkan terbentuknya struktur multi organisasi yang bersifat sementara. Dilihat dari differensiasi, kompleksitas organisasi proyek terbagi menjadi dua yaitu: vertikal, terkait dengan stuktur hirarki organisasi; dan horizontal, melihat kepada unit organisasi dan struktur tugas. Sedangkan dari sudut pandang interdepedency setiap level dan unit dari organisasi akan saling tergantung satu dengan lainnya dalam melaksanakan tugas dan tanggung jawabnya (Baccarini, 1996).

\section{Kompleksitas teknologi}

Sampai saat ini masih ada kesenjangan pendapat dan belum ada suatu definisi konseptual yang pasti dari "teknologi". 
Teknologi dapat dipahami sebagai suatu konsep multi-dimensi yang terdiri atas ketidakpastian dan kompleksitas. Teknologi mencakup tiga area yaitu operasional; karakteristik material dan karakteristik pengetahuan.

Jika dilihat dari sudut pandang differensiasi, kompleksitas teknologi menunjukkan adanya berbagai macam aspek dan tugas yang harus dilaksanakan seperti jumlah dan diversifikasi masukan dan keluaran; jumlah tindakan yang berbeda untuk memproduksi hasil akhir suatu proyek; jumlah keahlian seperti subkontraktor dan supplier yang terlibat di proyek. Sedangkan dari sisi interdepedency, setiap aspek dan tugas tersebut akan memiliki saling ketergantungan sendiri dalam penyelesaian pekerjaan secara keseluruhan. Ketergantungan yang terjadi dapat berupa antara pekerjaan, jaringan tugas-tugas, tim kerja, teknologi yang berbeda dan masukan (Baccarini, 1996).

\section{Pengadaan pekerjaan konstruksi}

Pengadaan konstruksi dapat didefinisikan dengan banyak cara dan telah menjadi topik yang kompleks dan sulit, terlebih lagi dengan karakteristik proyek konstruksi yang unik. Hal ini dikarenakan proses pengadaan tidak hanya mengacu pada apa yang akan dibeli, tetapi juga menentukan metode yang akan digunakan untuk mendapatkan bangunan dan fasilitas infrastruktur lainnya (Hughes dkk, 2006:7). Pengadaan adalah proses utama dari pelaksanaan dan pemeliharaan pekerjaan konstruksi yang selalu membutuhkan barang dan jasa dari organisasi lain untuk memenuhi kebutuhannya (Watermeyer, 2012:1).
Mohsini dan Davidson (1989:86), mendefinisikan pengadaan konstruksi sebagai proses akuisisi bangunan baru atau ruang dalam bangunan, baik dengan pembelian langsung, menyewa atau leasing dari pasar terbuka, atau dengan merancang dan membangun fasilitas untuk memenuhi kebutuhan khusus. Terkait dengan hubungan antara pengadaan dan inovasi maka pengadaan dapat didefinisikan sebagai strategi untuk memenuhi kebutuhan pengembangan dan/atau operasional klien terkait dengan penyediaan fasilitas yang akan dibangun untuk discrete life-cycle (Lenard dan Mohsini, 1998:79).

Hal ini menekankan bahwa strategi pengadaan harus mencakup semua proses sesuai keinginan klien yang mungkin akan meliputi seluruh umur bangunan. Pengadaan pekerjaan konstruksi merupakan proses akuisisi dari berbagai sumber daya proyek dalam merealisasikan fasilitas yang akan dibangun (Rowlinson, 1999:29; Walker dan Rowlinson, 2007:43) mendefiniskan pengadaan sebagai proses akuisisi sumber daya proyek untuk merealisasikan pembangunan fasilitas.

\section{Gambaran kompleksitas proyek konstruksi di Indonesia}

Perkembangan industri konstruksi di Indonesia dari tahun ke tahun semakin meningkat sejalan dengan program pembangunan yang dilaksanakan oleh pemerintah. Stakeholder yang terlibat dalam industri konstruksi di Indonesia bukan hanya pemerintah akan tetapi juga pihak swasta nasional maupun swasta asing, dimana terdapat 182.800 perusahaan kontraktor dengan kualifikasi besar (1\%), kualifikasi menengah (12\%) dan kualifikasi kecil 
(87\%). Komposisi ini didominasi perusahaan kontraktor umum (general contractors) dan sedikit perusahaan kontraktor khusus (specialist contractors). Secara hipotetik, $85 \%$ nilai pasar konstruksi dikuasai oleh non-kecil dengan jumlah $13 \%$ dari total 182.800 badan usaha, sedangkan $15 \%$ nilai pasar konstruksi diperebutkan oleh kontraktor kecil dengan jumlah $87 \%$ dari total 182.800 badan usaha. Keadaan ini menyebabkan persaingan usaha di pasar konstruksi skala kecil menjadi tidak sehat dan terdistorsi (Suraji dan Krishna, 2012:3). Pasar konstruksi di daerah juga masih dikuasai oleh proyek pemerintah yang dibiayai dana APBN maupun APBD.

Karakteristik proyek konstruksi di Indonesia sedikit banyak turut dipengaruhi oleh berbagai faktor seperti sumber daya yang digunakan, kompleksitas teknis pekerjaan, lingkungan, organisasi proyek, kompleksitas desain dan konstruksi, kondisi dan permasalahan di site, teknik dan metode konstruksi, kompleksitas desain proses komunikasi dan pendelegasian kekuasaan, ambiguitas dan ketidakjelasan kriteria kinerja proyek dan lain-lain (Xia dan Chan, 2011). Dengan karakteristik wilayah, budaya dan keragaman suku bangsa Indonesia, factor yang mempengaruhi kompleksitas proyek konstruksi akan lebih banyak. Faktor-faktor lainnya yang akan turut mempengaruhi kompleksitas proyek konstruksi, seperti kearifan budaya lokal, intervensi pemangku kepentingan, kondisi geografis, budaya kerja, kemampuan sumber daya manusia dan lain sebagainya.

Keterlibatan berbagai stakeholder terutama pada proyek pemerintah menyebabkan secara organisasi proyek cenderung lebih "gemuk", terlebih lagi untuk proyek dengan menggunakan dana bantuan luar negeri. Berbagai hal ditengarai menjadi penyebabnya antara lain terkait dengan transparansi, akuntabilitas dan kepercayaan publik terhadap proses yang dilaksanakan. Terlebih lagi proyek pemerintah menggunakan alokasi dana publik, sehingga perlu dipastikan hasil pelaksanaannya akan memberikan nilai manfaat bagi masyarakat dari besaran nilai yang dibelanjakan. Jika melihat dari jenis alokasi dana yang digunakan, proyek konstruksi pemerintah menggunakan dana yang berasal dari APBN/APBD murni, bantuan/hibah dari luar negeri atau gabungan APBN/APBD dengan bantuan luar negeri. Alokasi dana ini sedikit banyak turut berkontribusi terhadap kompleksitas organisasi proyek sebagaimana terlihat pada pada Gambar 2 yang merupakan Proyek Pengembangan Institut Teknologi Bandung III dengan alokasi dana bantuan Luar Negeri.

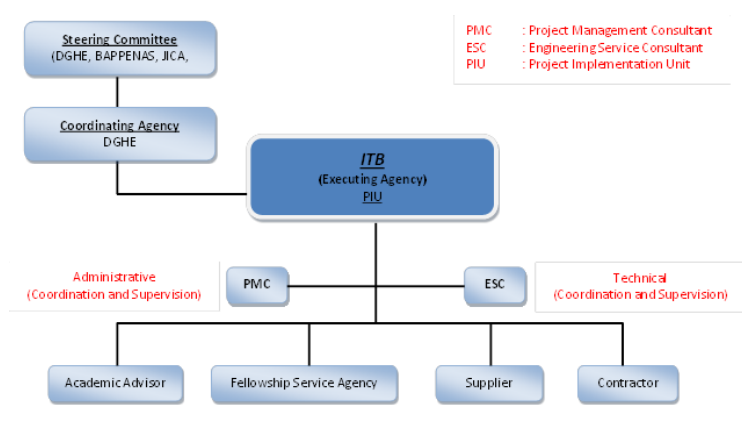

Gambar 2 Struktur Organisasi dari Project Implementasi Unit (PIU) ITB

Dari gambar tersebut terlihat begitu banyaknya pihak yang terlibat secara kelembagaan dan pada setiap sub-bagiannya memiliki struktur organisasi internal tersendiri, terutama kontraktor pelaksana. Agar interaksi antar pihak yang terlibat berjalan dengan baik tentunya dibutuhkan suatu sistem pengelolaan proyek sehingga 
akan menghasilkan proyek dengan jaminan mutu sesuai harapan. Kompleksitas ini baru terlihat dari sudut organisasi dan belum tergambar kompleksitas dalam penggunaan teknologi pada pelaksanaan pekerjaan di lapangan. Kompleksitas teknologi yang tentunya akan lebih kompleks mengingat pembangunan yang dilaksanakan merupakan bangunan berlantai banyak dengan berbagai keterbatasan.

\section{Pengadaan pekerjaan kompleks di Indonesia}

Mengacu pada Perpres 54/2010 dan peraturan perubahannya, pekerjaan kompleks adalah pekerjaan yang memerlukan teknologi tinggi, mempunyai risiko tinggi, menggunakan peralatan yang didesain khusus dan/atau pekerjaan yang bernilai diatas Rp. 100 Miliar. Beberapa ketentuan pelaksanaan pengadaan pekerjaan kompleks antara lain : pemilihan penyedia jasa dilakukan dengan metode Pelelangan Umum, akan tetapi jika jumlah penyedia yang mampu melaksanakan diyakini terbatas maka dilakukan dengan metode Pelelangan Terbatas (Pasal 1 ayat 24); penyampaian dokumen penawaran dilakukan dengan metode dua tahap (Pasal 47 ayat 6); evaluasi dokumen penawaran dapat dilakukan menggunakan metode evaluasi sistem nilai atau metode evaluasi penilaian biaya selama umur ekonomis (Pasal 48 ayat 3); penilaian kualifikasi penyedia jasa dilakukan dengan metode prakualifikasi (Pasal 56 ayat 9); penandatanganan kontrak dilakukan setelah memperoleh pendapat ahli hukum kontrak (Pasal 86 ayat 4). Tahapan pelaksanaan kegiatan pengadaan pekerjaan konstruksi yang bersifat kompleks sebagaimana terlihat pada Gambar 3.

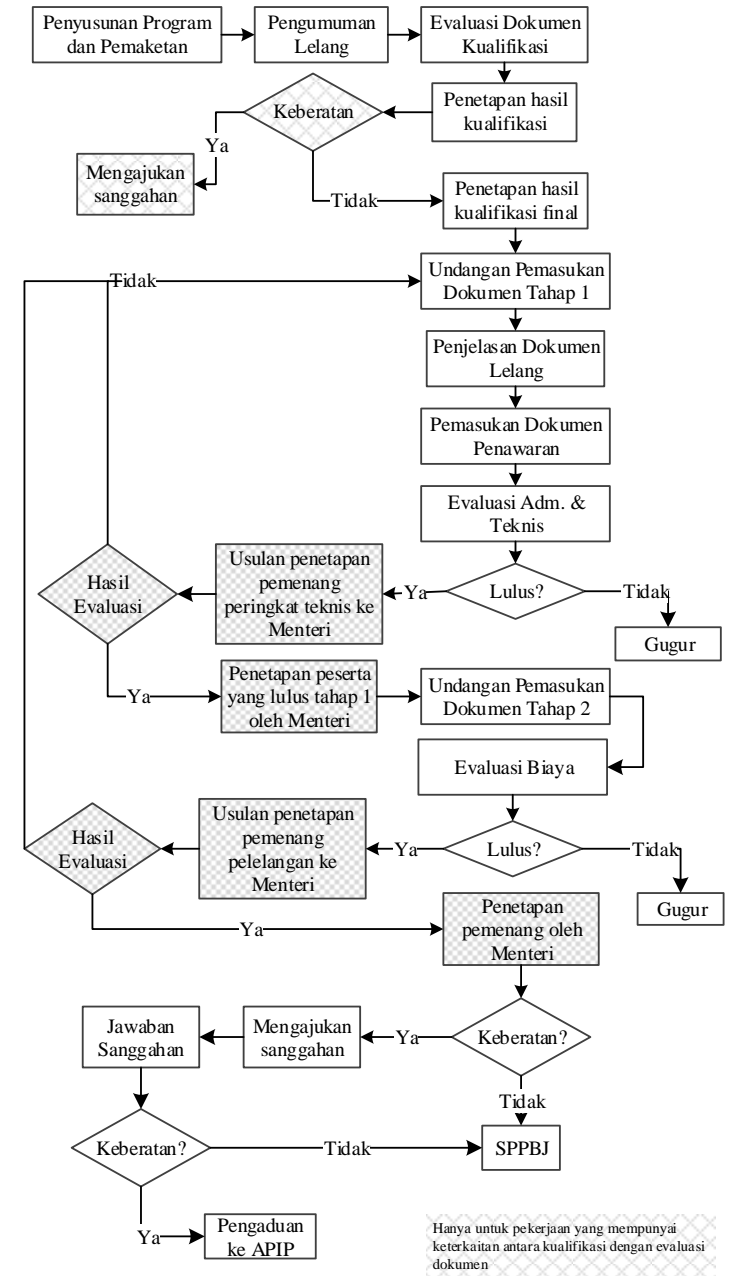

Gambar 3 Tahapan pengadaan pekerjaan konstruksi kompleks (Perpres 4/2015 dan Perka LKPP 01/2015)

Pelaksanaan pengadaan pekerjaan kompleks dengan tahapan sebagaimana terlihat pada Gambar 3 tentunya akan melibatkan banyak pihak. Berikut akan disajikan gambaran hubungan antar pihak dalam pelaksanaan pengadaan barang/jasa di Kementerian PUPR sebagaimana terlibat pada Gambar 4. Pelaksanaan pengadaan pekerjaan konstruksi pada Kementerian PUPR secara kelembagaan dilaksanakan oleh ULP yang berkedudukan pada BBWS, BWS dan BBPJN yang tersebar di seluruh Indonesia. 


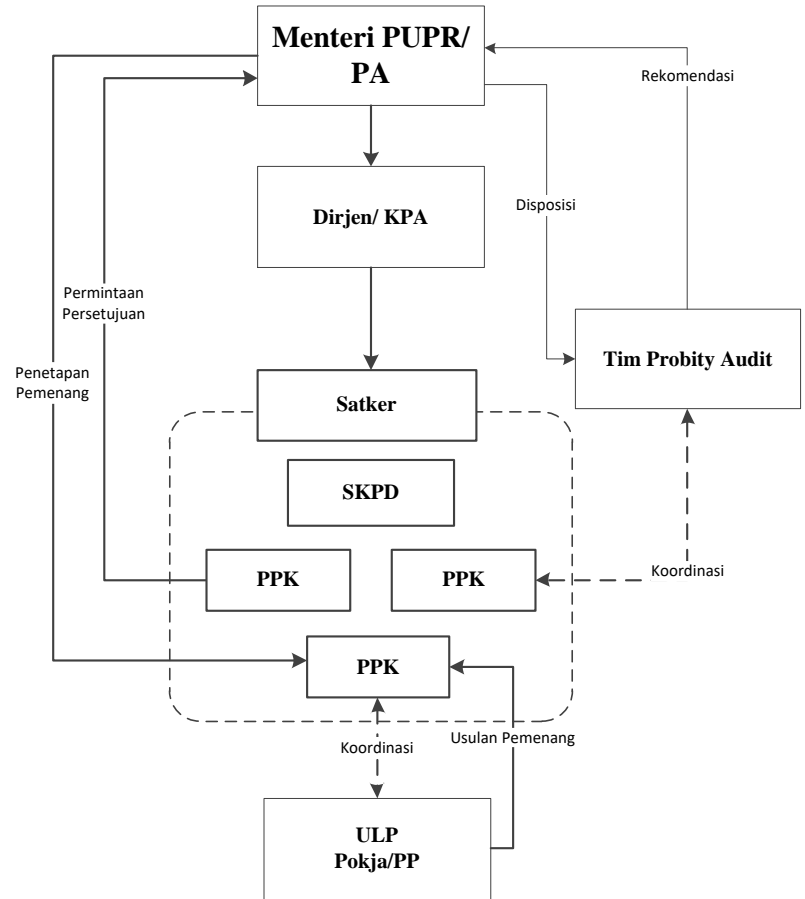

Gambar 4 Hubungan antar pihak pada pengadaan pekerjaan konstruksi kompleks di Kementerian PUPR

Point penting lainnya dalam ketentuan pelaksanaan pengadaan pekerjaan kompleks yaitu implementasi dari Pasal 86 ayat 4 dilakukan melalui mekanisme khusus yang sangat tergantung pada K/L/D/I pelaksana pengadaan. Sebagai contoh pada pelaksanaan pengadaan di Kementerian Ristek dan Dikti, berdasarkan surat edaran Dirjen Dikti Nomor 98/E/KU/2013 tanggal 5 Februari 2013 perihal pelaksanaan APBN dan APBN-P untuk pelaksanaan pengadaan dilakukan proses pendampingan oleh LKPP, Kejaksaan dan BPKP. Pendampingan ini dimaksudkan untuk menjamin akuntabilitas dalam pelaksanaan belanja modal, barang/jasa di Kementerian Pendidikan Nasional. Laporan hasil pendampingan ini akan menjadi pertimbangan bagi Pengguna Anggaran untuk menetapkan pemenang setiap tahapan pelelangan. Gambar 5 memperlihatkan proses pengadaan pekerjaan konstruksi kompleks.

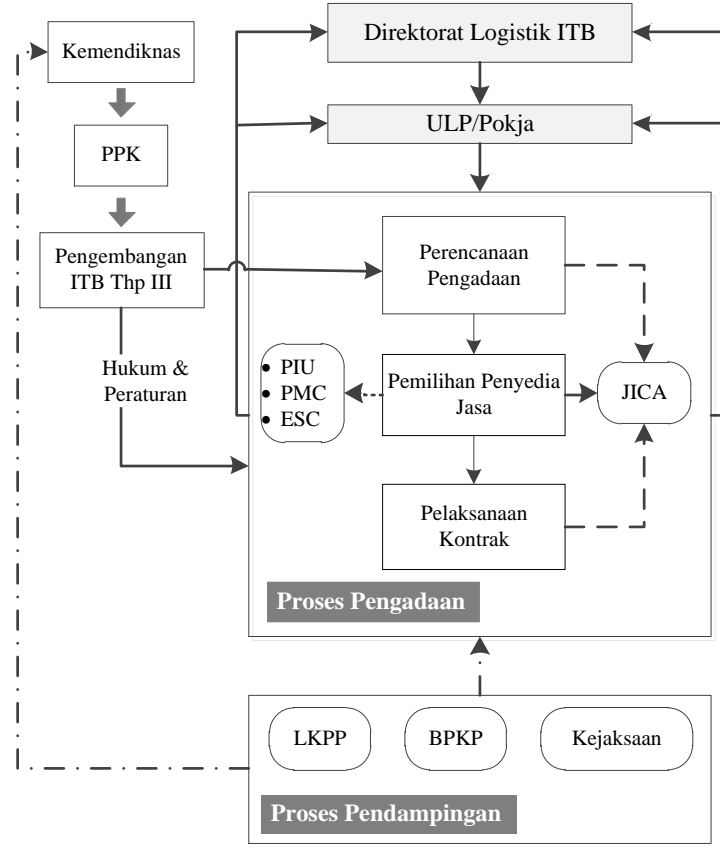

Gambar 5 Proses Pengadaan Proyek Pengembangan ITB Tahap III

Berdasarkan gambar tersebut, pihak-pihak yang terlibat dalam pengadaan :

- JICA selaku pemberi bantuan yang akan memberikan Concurrence terhadap proses dan hasil pelaksanaan pada tahapan yang telah disepakati dalam Loan Agreement.

- PIU, PMC dan ESC yang bertindak sebagai supporting teknis pada saat penyusunan bidding document, penjelasan teknis saat pre-bid technical meeting, bid evaluation (membantu analisis teknis dan finansial) dan lain sebagainya.

- LKPP, BPKP, Kejaksaan bertindak sebagai perpanjangan tangan pemilik dalam hal ini Kementerian Pendidikan Nasional untuk melakukan pendampingan sebagai upaya penjaminan akuntabilitas proses pengadaan yang dilaksanakan 
Sementara pada Kementerian PUPR proses penetapan pemenang pada tahap evaluasi administrasi dan teknis serta evaluasi biaya dilakukan oleh tim evaluasi yang dibentuk oleh menteri. Alur tahapan proses evaluasi sampai dengan penetapan menteri sebagaimana terlihat pada Gambar 6.

Proses evaluasi untuk penetapan pemenang pada tahap evaluasi teknis, administrasi dan teknik berada dibawah kewenangan Direktur Jenderal Bina Penyelenggaraan Jasa Konstruksi Kementerian PUPR. Tim evaluator dibentuk oleh menteri dan bertanggungjawab kepada menteri. Tim ini terdiri dari beberapa personil yang akan memastikan bahwa proses pemilihan telah berjalan sesuai dengan kerangka peraturan dan perundangan yang berlaku.

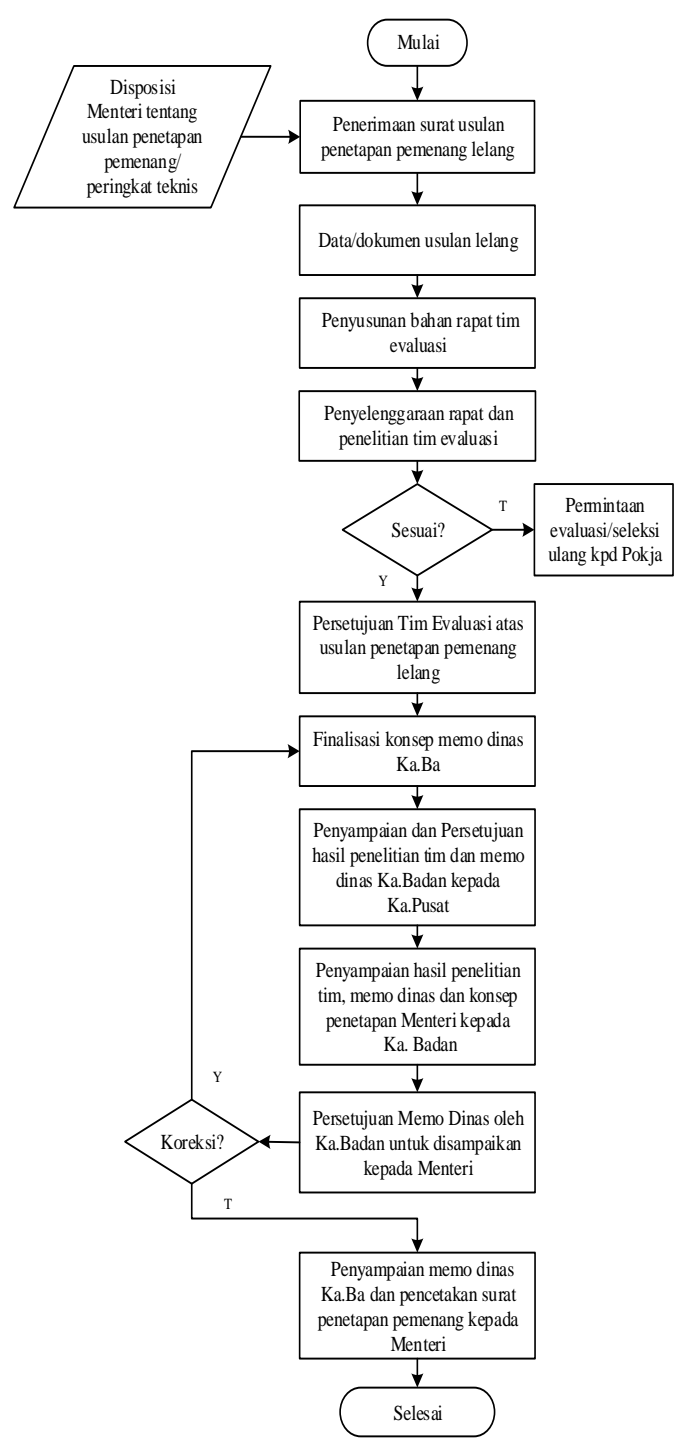

Gambar 6 Alur Evaluasi dan Penetapan

Pemenang Pengadaan

(Sumber : Kementerian PUPR, 2015)

\section{SIMPULAN}

Kompleksitas pekerjaan konstruksi tidak tergantung pada besar kecilnya ukuran suatu proyek, proyek kecil dapat saja bersifat lebih kompleks dari pada proyek dengan ukuran yang lebih besar. Kompleksitas proyek tidak hanya pada tahap pelaksanaan akan tetapi meliputi keseluruhan siklus proyek konstruksi. Pada tahap pengadaan pekerjaan konstruksi, kompleksitas organisasi dan proses menjadi perhatian utama terlebih pada pengadaan pemerintah. 
Kompleksitas memerlukan pengaturan dan pengendalian yang sedemikian rupa sehingga tidak terjadi benturan-benturan pada setiap tahapan dari siklus proyek konstruksi.

\section{DAFTAR PUSTAKA}

Peraturan Presiden Republik Indonesia Nomor 4 Tahun 2015 tentang Perubahan Keempat Atas Peraturan Presiden Nomor 54 Tahun 2010 tentang Pengadaan Barang/Jasa Pemerintah, Jakarta

Peraturan Kepala Lembaga Kebijakan Pengadaan Barang/Jasa Pemerintah No. 14 Tahun 2012 tentang Petunjuk Teknik Peraturan Presiden Republik Indonesia Nomor 70 Tahun 2012 tentang Perubahan Kedua Atas Peraturan Presiden Nomor 54 Tahun 2010 tentang Pengadaan Barang/Jasa Pemerintah, Jakarta

Baccarini, D., 1996, The Concept of Project Complexity - a Review, International Journal of Project Management, Vol. 14, No. 4, pp. 201-204, 1996

Bertelsen, S., 2003, Construction as a Complex System, Proceedings of IGLC-11, Blacksburg, Virginia

Bertelsen, S., 2003, Complexity Construction in a New Perspective, Proceedings of IGLC-11, Blacksburg, Virginia

Edmonds, G.A., and Miles, D.W.J., 1984, Foundations for Change: Aspects of the Construction Industry in Developing Countries, London: Intermediate Technology Publications Ltd

Hughes, W., Hillebrandt, P., Greenwood, D., and Kwawu, W., 2006, Procurement in the Construction Industry, The Impact and Cost of Alternative Market and Supply Processes, Taylor and Francis, London, USA

Larasati, D., 2011, Development of Contractor Quality Assurance System in Indonesia Construction Procurement, unpublished Doctor of Philosophy dissertation, Graduate School of Engineering, Kochi University of Technology, Kochi, Japan

Lenard, D. and Mohsini, R., 1998, 'Recommendations from the organisational workshop', in C.H.Davidson (ed.) Procurement - the way forward: Proceedings of CIB W92 Montreal Conference, Université de Montréal, Montréal, CIB publication 203, 79-81

Mohsini, R. and Davidson, C.H., 1989, 'Building Procurement-Key To Improved Performance', in D. Cheetham, D. Carter, T. Lewis, and D.M. Jaggar (eds) Contractual Procedures for Building : Proceedings of the International Workshop, 6-7 April, University of Liverpool, Liverpool,

USchalcher, H.R., 2007, Complexity in Construction

Rowlinson, S. dan McDermott, P., 1999, Procurement System, a Guide to Best Practice in Construction, E dan FN Spon, Taylor dan Francis Group, London, ISBN 0-203-98278-9

Suraji, A. dan Pribadi, K.S., 2012, Membangun Struktur Industri Konstruksi Nasional yang Kokoh, Andal dan Berdaya Saing serta Memberikan Kesempatan Kepada Para Pelaku Usaha Tumbuh dan Berkembang Secara Adil Melalui 
Kajian Kompleksitas Proyek... (Cut/ hal. 35-45)

Restrukturisasi Sistem, Consolidated Paper

Walker, D.H.T., and Rowlinson, S., 2007, Procurement System, a Cross-Industry Project Management Perspective, Taylor and Francis, London

Watermeyer, R., 2012, Changing The Construction Procurement Culture To Improve Project Outcomes, Joint CIB W070, W092 and TG72 International Conference on Facilities Management, Procurement Systems and Public Private Partnerships, Cape Town, 23rd to 25th January 2012

Wiyana, Y.E., 2012, Analisis Kegagalan Konstruksi dan Bangunan dari Perspektif Faktor Teknis, Wahana Teknik Sipil Vol.17 No.2 Desember 2012 77-86, http://www.polines.ac.id/wahana/uplo ad/jurnal/jurnal_wahana_1374559769. pdf

Yunus, R., M, 2006, Kegagalan Dini Perkerasan Jalan Akibat Pelaksanaan Konstruksi, "Mektek" Tahun VIII No.1 Januari 2006, http://jurnalmektek.files.wordpress.co m/2012/04/8_ruslan-so-edit-jan20062.pdf

Xia, Bo \& Chan, Albert, 2011, Measuring Complexity for Building Projects : a Delphi Study, Engineering, Construction and Architectural Management, 19(1), pp. 7-24 http://eprints.qut.edu.au/48623/ 